
K

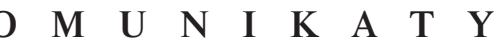
M A T
$\begin{array}{lllllll} & \text { E } & \mathbf{R} & \text { I } & \text { A } & \mathbf{L} & \mathbf{Y}\end{array}$

Piotr Daszkiewicz

Instytut Historii Nauki im. L. i A. Birkenmajerów PAN

\title{
LIST JANA BERNARDA MILEGO (1789-1839) \\ DO HENRI-MARIE DUCROTAY DE BLAINVILLE'A (1777-1850) W ZBIORACH BIBLIOTEKI GEÓWNEJ NARODOWEGO MUZEUM HISTORII NATURALNEJ (MNHN) W PARYŻU
}

Biblioteka Główna MNHN przechowuje bogate archiwum rękopisów i korespondencji Henri-Marie Ducrotay de Blainville’a, anatoma, zoologa i profesora, następcy Jean-Baptiste'a Lamarcka (1744-1825) na muzealnej katedrze historii naturalnej i Georgesa Cuviera (1769-1832) na katedrze anatomii porównawczej. Wśród naukowych zasług tego uczonego przypomina się zazwyczaj jego wkład do narodzin współczesnej systematyki m.in. rozdzielenie płazów i gadów na dwie odrębne grupy taksonomiczne, jak i dyskusję pozycji systematycznej dziobaka wraz ze stworzeniem podstaw współczesnej klasyfikacji ssaków oraz liczne prace z dziedziny malakologii, fizjologii i paleontologii. W swojej koncepcji paleontologicznej H.M. de Blainville rozwinął teorię „brakującego ogniwa”, a także zwracał uwagę na możliwość wyginięcia gatunku nie w rezultacie katastrof, lecz działania człowieka ${ }^{1}$. Znaczący wpływ na biologię dziewiętnastego wieku wywarły także badania tego uczonego prowadzone nad układem nerwowym, strukturą mózgu i funkcjami jego poszczególnych części². H.M. de Blainville zajmował się także historią i filozofią nauki ${ }^{3}$. Za pośrednictwem Claude-Henriego Saint-Simona (1760-1825) poznał on Auguste’a Comte’a (17981857), z którym przez lata współpracował. To właśnie H.M. de Blainvillowi A. Comte zawdzięczał znajomość podstawowych zagadnień filozofii biologii, które przed-

\footnotetext{
${ }^{1}$ T.A. A p p el: Henri de Blainville and the Animal Series: A Nineteenth-Century Chain of Being, , Journal of the History of Biology" t. 13: 1980 s. 291-319.

${ }^{2}$ L. C l a u z a d e: La théoreme cérébrale d'un naturaliste spiritualiste, Henri- Marie Ducrotay de Blainville, „Revue d'histoire des sciences” t. 62: 2010 s. 237-257.

${ }^{3}$ A.F. S h u ster : Note sur H. de Blainville, historien de biologie, „Revue d'histoire des sciences" t. 25: 1972 s. 191-200.
} 
stawił w trzecim tomie Cours de philosophie positive ${ }^{4}$. Epistemologiczne prace tego uczonego, a zwłaszcza jego Histoire des sciences de l’organisation, wielokrotnie były badane i doceniane przez historyków nauki ${ }^{5}$.

Począwszy od 1814 r. H.M. de Blainville wykładał w MNHN anatomię porównawczą, najpierw wspólnie z G. Cuvierem, a następnie sam. Jego wykład zatytułowany był „Sur la sensibilité, les organes des sens et le système nerveux” ( 0 wrażliwości, organach zmysłu i systemie nerwowym). Rękopis tych wykładów przechowywany jest w Bibliotece Glównej MNHN, a ich treść poddana została analizie z punktu widzenia historii fizjologii i badań biologii mózgu ${ }^{6}$. Właśnie na te wykłady uczęszczał w 1816 r., jak wynika z treści listu przechowywanego w tym samym miejscu ${ }^{7}$, J.B. Mile. Znaczenie MNHN i muzealnych wykładów dla polskich nauk przyrodniczych w okresie zaborów było tematem odrębnego opracowania ${ }^{8}$. Informacja na temat uczestnictwa J.B. Milego w wykładach H.M. de Blainville’a jest interesującym, nieznanym dotychczas przyczynkiem zarówno dla biografii warszawskiego uczonego, jak i dla historii związków MNHN z polską nauką. Biogram J.B. Milego w Polskim Słowniku Biograficznym na temat jego studiów we Francji informuje nas jedynie, że

Odbył własnym kosztem podróż naukową (1814-1817), zwiedzając uniwersytety w Niemczech, Anglii, Holandii, Austrii, Francji, Szwajcarii, Włoszech; szczególnie zajmował się, fizjologią, chirurgią, akuszerią, okulistyką, naukami przyrodniczymi, mechaniką i górnictwem ${ }^{9}$.

Listy słuchaczy wykładów w MNHN, zachowane jedynie bardzo fragmentarycznie, pozwalają na ustalenie, że J.B. Mile uczestniczył w 1816 r. w wykładach mineralogii René-Just Haüy'ego (1743-1822) ${ }^{10}$ oraz w wykładach zoologii bezkręgowców J.-B. Lamarcka. Dotychczas nie odnaleziono list słuchaczy wykładów anatomii porównawczej, stąd list J.B. Milego do H.M. de Blainville'a jest także cennym świadectwem historii nauczania w MNHN.

${ }^{4}$ H. Gouhier: Blainville et Auguste Comte, „Revu d'histoire des sciences” t. 32: 1979 s. $59-72$.

${ }^{5}$ G. Canguilhem: L' «Histoire des sciences de l'organisation» de Blainville et l'abbé Maupied, „Revue d'histoire des sciences” t. 32: 1979 s. 73-91.

${ }^{6}$ L. Cl a u za d e: dz. cyt.

${ }^{7}$ Sygnatura Ms BLA 8.

${ }^{8}$ P. Daszki ewicz: Znaczenie nauczania w Narodowym Muzeum Historii Naturalnej w Paryżu dla polskiej nauki okresu zaborów „Nauka Polska” t. 23/48: 2014 s. 103-110.

${ }^{9}$ T. O s trow ska: Mile Jan Szczęsny (1789-1839) [w:] Polski Słownik Biograficzny, t. 21: 1976 s. 199-201.

${ }^{10}$ P. Daszkiewicz, R. Tarkowski: Polacy - słuchacze wykładów mineralogii R.J. Haüy w Narodowym Muzeum Historii Naturalnej w Paryżu w latach 1802-1821, „Przegląd Geologiczny" t. 56: 2006 s. 215-218. 
Począwszy od 1813 r. H.M. de Blainville współredagował wraz z Jean-Claude’em Delamétherie (1743-1817), Journal de physique, de chimie, d'histoire naturelle et des arts, niewątpliwie jedno z najważniejszych pism naukowych przełomu osiemnastego i dziewiętnastego wieku. W latach 1817-1823 H.M. de Blainville był jego redaktorem naczelnym. Właśnie jako do redaktora tego pisma zwraca się do niego J.B. Mile, dziękując za opublikowanie artykułu i prosząc o druk kolejnych publikacji. Jednakże pismo przestało ukazywać się już w 1823 r. i żaden inny z tekstów przysłanych przez warszawskiego uczonego nie został w nim zamieszczony. W archiwum H.M. de Blainville’a w Bibliotece Glównej MNHN nie ma żadnego z nadesłanych tekstów, ani też jakiegokolwiek śladu późniejszej współpracy tych uczonych. Poniżej tłumaczenie treści listu.

\section{Panie Profesorze,}

Miałem szczęście w 1816 roku być wśród słuchaczy wykładów Pańskich jak i innych wybitnych Profesorów z Paryża, dla których, moje uznanie nigdy się nie skończy. Szczęście to daje mi śmiałość, napisania do Pana, korzystając z wyjazdu moich rodaków do stolicy nauki.

Był Pan tak dobry włączając do pańskiego słynnego pisma (listopad 1822) moja rozprawę na temat widocznej wielkości ciał niebieskich ${ }^{11}$.W ten sposób upoważnił mnie Pan do ośmielenia się złożenia niniejszej prośby, wydrukowania innych rozpraw, które właśnie Panu przekazałem. Nie odrzucam wszystkich zarzutów Pana [słabo czytelny wyraz] Georgonne ${ }^{12}$, które przedstawił w omówieniu mojej pracy, ale znalazłem obecnie nowe wyjaśnienie tego zjawiska, które przekażę Panu później, ponieważ nie jest jeszcze ukończone. W oczekiwaniu proszę przyjąć cztery moje rozprawy przetłumaczone z polskiego, a mianowicie

1. Opis nowej maszyny pneumatycznej nie posiadającej tłoku, zaworu, kurków itp.

2. Opis nowej maszyny służącej do wytwarzania wysokiej temperatury ${ }^{13}$

3. Opis nowego barometru ${ }^{14}$

${ }^{11}$ Chodzi o Lettre de Jean Mile, Professeur de Physiologie, à J.C. Skrodzki, professeur de Physique dans l'Université de Varsovie, écrite le 20 juin 1821, sur la grandeur apparente des objets causée par la réfraction de la lumière dans l'atmosphère. „Journal de Physique, de Chimie et d'Histoire Naturelle" t. 95: 1822, novembre, s. 321-330. Jest francuskie tłumaczenie tekstu opublikowanego w 1821 roku w Pamiętniku Warszawskim: List Jana Mile do J. K. Skrodzkiego pisany dnia 20 czerwca 1821 o pozorney wielkości przedmiotów, wynikającey z łamania się światła $w$ atmosferze.

${ }^{12}$ Nie udało się ustalić ani tożsamości autora ani cytowanego tekstu.

${ }^{13}$ Zapewne chodzi o maszyny opisane w Opisanie nowych narzędzi: 1. machiny pneumatycznéj, 2. apparatu do wydania wysokiego stopnia ciepła wynalezionych przez Jana Milego. Warszawa 1822.

${ }^{14}$ Być może chodzi o rozprawę przedstawioną na posiedzeniu Towarzystwa Naukowego Warszawskiego 19 listopada 1823: Myśl pewnej odmiany barometru dla dokładniejszego okaznia drobnych jego zmian, patrz A. Kraushar Towarzystwo Królewskie Przyjaciół Nauk. Księga III. Czasy Królestwa Kongresowego 1820-1824, Kraków, Warszawa 1904, s. 404-407. 


\section{Rozprawę o achromatyzmie oka ${ }^{15}$}

Mam nadzieję, że nie odmówi Pan prośbie włączenia do Pańskiego czasopisma tych tekstów najszybciej jak będzie to możliwe, i tych, które wkrótce wyślę Panu za pośrednictwem Pana Fallinier, jeśli uzna je Pan za godne publikacji w Pańskim czasopiśmie.

Ponieważ władam francuskim jedynie niedoskonale, byłem zmuszony zlecić tłumaczenie innym osobom. Proszę wybaczyć cudzoziemcowi błędy konstrukcji i ortografii w Pańskim języku i proszę o uprzejmość ich poprawienia, proszę o to Pana bardzo.

Polecając Panu moich rodaków, lekarzy, Panów Fallinier i Le Brun ${ }^{16}$

Mam zaszczyt być Panu oddanym

Dr Jean Milé - Profesor Fizjologii Uniwersytetu Warszawskiego

${ }^{15}$ Rozprawę tę J.B. Mile przedstawił na posiedzeniu Uniwersytetu Warszawskiego 13 lipca 1821 roku. A. Krausha, dz. cyt. s. 245.

${ }^{16}$ Aleksander Le Brun (1803-1868) wybitny warszawski chirurg i lekarz, wyjeżdżał wtedy na studia do Paryża, gdzie kilka lat później obronił doktorat na podstawie pracy o kołtunie: Essai médical sur la plique polonaise ; Thèse présentée et soutenue à la Faculté de médecine de Paris, le 30 mars 1827, pour obtenir le grade de Docteur en médecine par Alexandre Antoine Le Brun (Polonais), Maître en médecine et chirurgie, de l'Université royale de Varsovie. L'imprimerie de Didot jeune. Paryż. 